\title{
NON DESTRUCTIVE TESTING AND SERVICEABILITY PROPERTIES OF HIGH STRENGTH GLASS FIBER REINFORCED CONCRETE
}

\author{
Karthik B S \\ Assistant Professor, Civil Engineering Department, TJIT, Bangalore, India
}

\begin{abstract}
Concrete, an abundant material used in the construction industry uses huge amount of natural resources. These resources being exploited rapidly due to rapid growth in infrastructural construction resulted in the use of industrial wastes for concrete manufacture. The mechanical properties, durability properties are also important for the better understanding of the concrete to use it in the industry. Concrete of high grades such as M60 can be produced with fly ash, bottom ash and silica fume. In the present investigative study, Fly ash and silica fume combindly used as a cement replacement material at $15 \%$ and $10 \%$ respectively to that of cement. Bottom ash is used as a replacement to fine aggregate at the variable replacements of $0 \%, 10 \%$, 20\%, 30\%, 40\%\& 50\%. The compressive strength, non destructive tests such as rebound hammer test and ultrasonic pulse velocity test, durability tests like acid resistance, sorptivity were studied on the concrete. The observations showed that the concrete with constant replacements of fly ash and silica fume and 30\% bottom ash gave the optimum results to use.
\end{abstract}

Keywords: Acid Resistance, Bottom Ash, Non Destructive Tests, Sorptivity.

\section{INTRODUCTION}

Concrete being the soul of the construction industry is utilizing natural materials like natural sand, lime etc in very large quantities in turn depleting the natural availability and polluting the environment. Sustainable concrete using the waste materials of industries is the talk of the days and many researchers and scholars are working on utilizing these wastes in concrete. In this regard, fly ash and bottom ash the wastes of coal burning industries and silica fume from the production of crystalline silica are the few active materials that can be utilized in the concrete for the production of good sustainable concrete.

High strength concrete is becoming common in the modern construction world and is being used in the big infrastructural projects. M-60 grade concrete using the fly ash, silica fume and bottom ash as replacements to cement and fine aggregates can be produced and is the topic of the study. Fly ash and silica fume is used as the partial constant replacements of $15 \%$ and $10 \%$ respectively to that of cement. Fine aggregates are replaced with bottom ash as partial variable replacements of $0 \%, 10 \%, 20 \%, 30 \%, 40 \%$ $\& 50 \% .0 .2 \%$ of glass fibers were added to improve some of the strength properties. The concrete so produced was tested for strength and durability. Non destructive tests such as rebound hammer test and ultrasonic pulse velocity tests are the well known, simple and much accepted tests to know the strength and nature of the concrete at ages without causing any physical damage to the concrete. The values of these tests can be correlated with the actual strength results of the concrete. Acid attack is one of the problems facing by the concrete structures due to rapid industrialization and pollutions. The concrete with high resistance to acids has to be produce to suit the situation. In the present study the compressive test, non destructive tests viz. rebound hammer test and ultrasonic pulse velocity test, serviceability properties such as acid resistance test, sorptivity and density of concrete are studied and compared with the normal concrete. The concrete of 28, 56 and 90 days were tested. NDT values were correlated with the compressive strength results and the nature of the concrete is confessed in the work.

\section{LITERATURE SURVEY}

High strength concrete is becoming the norm of the day with the increase in infrastructural development. The industrial wastes are utilized as the partial alternate materials for the development of sustainable concrete. Fly ash and bottom ash being the waste of coal burning plants can be utilized up to a $30 \%$ optimum replacement levels to cement and fine aggregate [3][4][1][6]. Silica fume another industrial waste can be used as cement replacement for up to $10 \%$ [3][4]. When fly ash and silica fume both are used at a time, the optimum replacement levels changes to $15 \%$ and $10 \%$ respectively to that of cement. The glass fibers in the concrete can be used from $0.03 \%$ to $1 \%$ by the volume of concrete [5][6][8]. The previous studies [1][7][9] showed the bottom ash and glass fibers reduces the workability of concrete hence there is a need to use super plasticizer to increase the workability. The strength of bottom ash and fly ash concrete reduces at the initial ages but at the older ages it gains enough strength [1][6][7][9]. The NDT results shows that their values can be correlated to the strength and nature of the concrete [10][11]. In the present work, concrete with fly ash @ 15\%, silica fume @ 10\% both combindly used as cement replacement material, bottom ash @ $0 \%, 10 \%, 20 \%, 30 \%, 40 \% \& 50 \%$ to that of fine aggregate and glass fibers of $0.2 \%$ as extra ingredient are used and studied. 


\section{OBJECTIVES}

The work aims on studying the strength and durability properties of concrete. Non destructive tests such as rebound hammer test and ultrasonic pulse velocity are done and compared with the compressive strength results. The serviceability properties such as resistance of concrete to acids and sorptivity and density of concrete were studied.

\section{MATERIALS}

Cement- 53 grade ordinary Portland cement conforming to IS 12269-1987 with specific gravity 3.14, initial and final setting time 40 minutes and 195 minutes, fineness modulus $3.6 \%$ was used.

Fly ash- Fly ash of class F conforming to ASTM C 618 supplied from Raichur Thermal Power Station having specific gravity 2.2, fineness modulus $2.5 \%$ was used.

Bottom ash- Bottom ash supplied from RTPS, Raichur having specific gravity 2.6, Bulk compacted density 1420 $\mathrm{kg} / \mathrm{m}^{3}$ was used.

Fine aggregates- Natural river sand with specific gravity 2.65 , bulk compacted density $1624 \mathrm{~kg} / \mathrm{m}^{3}$ free from clay and silt was utilized.

Coarse aggregates- Crushed angular shaped stones having specific gravity 2.68 , bulk compacted density $1599 \mathrm{~kg} / \mathrm{m}^{3}$ were used.

Glass fibers- Glass fibers with high chemical resistance Cem Fil Anti-crack HP of length $12 \mathrm{~mm}$, diameter 14 microns and aspect ratio 858 were used.

Mix design for M60 grade concrete was designed as per IS 10262-2009, The proportions of mix is shown as below.

Table-1: Mix proportion ratio

\begin{tabular}{|l|l|}
\hline \multicolumn{2}{|l|}{ M60 Grade conventional Concrete mix Proportion } \\
\hline Cement & $405.41 \mathrm{~kg} / \mathrm{m}^{3}$ \\
\hline Silica fume & $54.71 \mathrm{~kg} / \mathrm{m}^{3}$ \\
\hline Fly ash & $82.07 \mathrm{~kg} / \mathrm{m}^{3}$ \\
\hline Fine aggregate & $585.23 \mathrm{~kg} / \mathrm{m}^{3}$ \\
\hline Coarse aggregate & $1135.5 \mathrm{~kg} / \mathrm{m}^{3}$ \\
\hline Water & $174.15 \mathrm{~kg} / \mathrm{m}^{3}$ \\
\hline
\end{tabular}

Mix Ratio = C : FA : CA : w/c

Mix Ratio = 1:1.10:2.093:0.3 (1\% super plasticizer $)$

\section{METHODOLOGY, RESULTS AND}

\section{DISCUSSION.}

\subsection{Workability test}

The universally adopted slump cone test conforming to IS 1199-1959 was used to know the workability of the concrete mixes. The mixes with bottom ash, fly ash and silica fume showed a reduction in the workability with increase in bottom ash. Hence to achieve the workability within the range, slight increase in super plasticizer compared to normal concrete had to be made.

\subsection{Compressive Strength}

Compressive strength test using compressive testing machine on concrete cubes of $150 \mathrm{~mm}$ X $150 \mathrm{~mm}$ X $150 \mathrm{~mm}$ was done at the concrete ages of 28, 56 and 90 days. The maximum load at which the specimen fails to take is noted and compared with conventional concrete and correlated with rebound hammer test results.

\section{Compressive strength, $f_{c}=P / A$}

Where, $f_{c}=$ compressive strength of cube in $N / \mathrm{mm}^{2}$ $\mathrm{P}=$ compressive load causing failure in $\mathrm{N} / \mathrm{mm}^{2}$ $\mathrm{A}=$ Cross sectional area of cube in $\mathrm{mm}^{2}$

\subsection{Non Destructive Tests}

5.3.1 Rebound hammer test: This test gives rough estimation of strength and rigidity of concrete at various ages. The spring loaded steel rebound hammer is stuck on the concrete surface. The readings of rebound number shown on linear scale are noted. This number co-relates with strength of concrete and concretes rigidity. The variation of strength of the calibrated hammer ranges between $\pm 25 \%$.

5.3.2 Ultrasonic Pulse Velocity test: This non destructive test gives an idea of the internal structure of concrete. The analysis of propagation variation of ultrasonic sound waves gives a chance to know the compactness of concrete. The setup of instrument consisted of a amplifier, transmitter and receiving transducer connected to UPV testing equipment with a digital display was used. The velocity of waves passed can be directly read on the display of equipment. The test was conducted on $150 \mathrm{~mm}$ dia and $300 \mathrm{~mm}$ length cylinders. The concrete quality is said to be excellent if pulse velocity is above $4500 \mathrm{~m} / \mathrm{sec}$, good if at a range of $3500-4500 \mathrm{~m} / \mathrm{sec}$, medium if at a range of $3000-3500$ $\mathrm{m} / \mathrm{sec}$ and doubtful if below $3000 \mathrm{~m} / \mathrm{sec}$

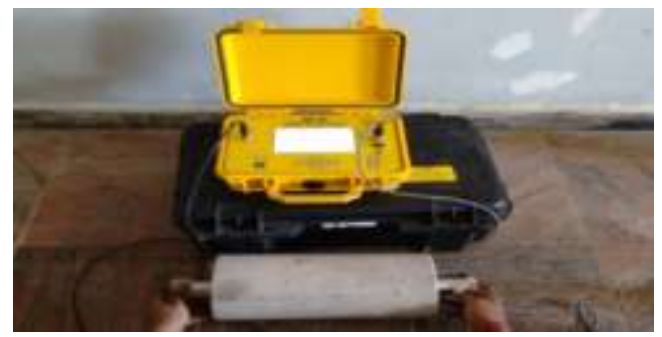

Fig - 1: Ultrasonic pulse velocity testing

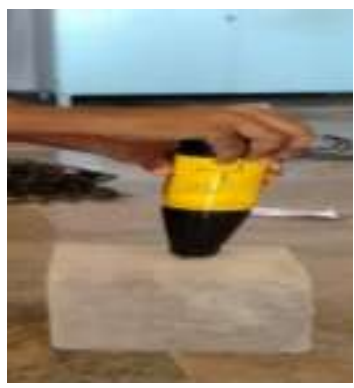

Fig - 2: Rebound hammer testing 
Table - 3: Rebound hammer numbers of M60 HSGFRC

\begin{tabular}{|c|c|c|c|c|c|c|c|}
\hline \multirow[b]{3}{*}{$\begin{array}{l}\text { Sl. } \\
\text { No. }\end{array}$} & \multirow{3}{*}{$\begin{array}{l}\% \\
\text { replacement } \\
\text { of bottom ash }\end{array}$} & \multicolumn{6}{|c|}{ Rebound number } \\
\hline & & \multicolumn{2}{|c|}{28 days } & \multicolumn{2}{|l|}{56 days } & \multicolumn{2}{|l|}{90 days } \\
\hline & & $\begin{array}{l}\text { Rebound } \\
\text { number }\end{array}$ & $\begin{array}{l}\text { Compressive } \\
\text { strength } \\
\left(\mathrm{N} / \mathbf{m m}^{2}\right) \\
\end{array}$ & $\begin{array}{l}\text { Rebound } \\
\text { number }\end{array}$ & $\begin{array}{l}\text { Compressive } \\
\text { strength } \\
\left(\mathrm{N} / \mathbf{m m}^{2}\right) \\
\end{array}$ & $\begin{array}{l}\text { Rebound } \\
\text { number }\end{array}$ & $\begin{array}{l}\text { Compressive } \\
\text { strength } \\
\left(\mathbf{N} / \mathbf{m m}^{2}\right) \\
\end{array}$ \\
\hline 1 & $\mathrm{CC}$ & 41 & 47.3 & 44 & 53.0 & 44 & 53.0 \\
\hline 2 & $0 \% \mathrm{BA}$ & 42 & 49.0 & 44 & 53.0 & 45 & 54.5 \\
\hline 3 & $10 \% \mathrm{BA}$ & 40 & 45.5 & 44 & 53.0 & 45 & 54.5 \\
\hline 4 & $20 \% \mathrm{BA}$ & 40 & 45.5 & 44 & 53.0 & 45 & 54.5 \\
\hline 5 & $30 \% \mathrm{BA}$ & 40 & 45.5 & 45 & 54.5 & 46 & 54.5 \\
\hline 6 & $40 \% \mathrm{BA}$ & 38 & 41.6 & 46 & 56.5 & 46 & 56.5 \\
\hline 7 & $50 \% \mathrm{BA}$ & 38 & 41.6 & 45 & 56.5 & 45 & 54.5 \\
\hline
\end{tabular}

Rebound hammer test showed a decline in rebound number at 28 days with increase in bottom ash. But at 56 and 90 days, the number increased with increment in bottom ash. This can be compared with the concrete compressive strength at all ages.

Table - 2: UPV values of M60 HSGFRC

\begin{tabular}{|l|l|l|l|l|}
\hline \multirow{2}{*}{$\begin{array}{l}\text { Sl. } \\
\text { No. }\end{array}$} & \multirow{2}{*}{$\begin{array}{l}\text { replacement of } \\
\text { bottom ash }\end{array}$} & \multicolumn{3}{|c|}{ Ultrasonic pulse velocity } \\
\cline { 3 - 5 } & $\mathbf{2 8}$ days & $\mathbf{5 6}$ days & 90 days \\
\hline 1 & CC & 4826.33 & 4864.28 & 4798.83 \\
\hline 2 & $0 \%$ BA & 4836.50 & 4892.30 & 4807.82 \\
\hline 3 & $10 \%$ BA & 4855.25 & 4842.64 & 4713.84 \\
\hline 4 & $20 \%$ BA & 4847.50 & 4739.55 & 4706.75 \\
\hline 5 & $30 \%$ BA & 4526.22 & 4592.32 & 4567.32 \\
\hline 6 & $40 \%$ BA & 4234.65 & 4272.92 & 4328.63 \\
\hline 7 & $50 \%$ BA & 4195.40 & 4213.52 & 4284.26 \\
\hline
\end{tabular}

Ultrasonic pulse velocity test noted a decrease in pulse velocity with increase in bottom ash in concrete at all ages. This shows that the internal structure of concrete is poor with increase in bottom ash. This is due to reduction in density of concrete with increased bottom ash and also due to porous nature of bottom ash. The concrete is excellent up to $30 \%$ replacement level of bottom ash and good later after.

\subsection{Acid resistance test}

The 28 days cured cube specimens were used for this test. The specimens were weighed and immersed in 1 molar $\mathrm{H}_{2} \mathrm{SO}_{4}$ solution and 1 molar $\mathrm{HCl}$ solutions for 28 days being maintained the $\mathrm{pH}$ level of solution. After 28 days of acid curing, the specimens were checked for weight loss and strength loss.

\section{Weight loss $(\%)=\left(\left(\mathrm{W}_{1}-\mathrm{W}_{2}\right) / \mathrm{W}_{1}\right) \times 100$}

Compressive strength loss $(\%)=\left(\left(\mathbf{f}_{\mathrm{c}}-\mathbf{f}^{1}\right) / \mathbf{f}_{\mathbf{c}}\right) \times 100$

The experimental work showed that the concrete with bottom ash at lower percentages have good resistance to acid attack but the concrete goes on fails to resist with increase in bottom ash content. The concrete with fly ash of upto $30 \%$ showed a better resistance to acid attack than conventional concrete. The reduction of concrete strength with increase in the bottom ash is due to increase in absorption capacity with increase in bottom ash.
Table - 4: Acid resistance of M60 HSGFRC

\begin{tabular}{|c|c|c|c|c|c|}
\hline \multirow[b]{2}{*}{$\begin{array}{l}\text { Sl. } \\
\text { No. }\end{array}$} & \multirow{2}{*}{$\begin{array}{l}\% \\
\text { replacement } \\
\text { of bottom } \\
\text { ash }\end{array}$} & \multicolumn{2}{|c|}{1 molar $\mathrm{H}_{2} \mathrm{SO}_{4}$} & \multicolumn{2}{|c|}{1 molar $\mathrm{HCl}$} \\
\hline & & $\begin{array}{l}\text { Wt. } \\
\text { loss } \\
(\%)\end{array}$ & $\begin{array}{l}\text { Strength } \\
\operatorname{loss}(\%)\end{array}$ & $\begin{array}{l}\text { Wt. } \\
\text { loss } \\
(\%)\end{array}$ & $\begin{array}{l}\text { Strength } \\
\operatorname{loss}(\%)\end{array}$ \\
\hline 1 & $\mathrm{CC}$ & 8.02 & 7.18 & 0.01 & 6.63 \\
\hline 2 & $0 \% \mathrm{BA}$ & 3.54 & 5.97 & 0.01 & 5.73 \\
\hline 3 & $10 \% \mathrm{BA}$ & 4.59 & 6.69 & 0.01 & 6.13 \\
\hline 4 & $20 \% \mathrm{BA}$ & 5.31 & 6.80 & 0.02 & 6.23 \\
\hline 5 & $30 \% \mathrm{BA}$ & 7.95 & 7.28 & 0.02 & 6.53 \\
\hline 6 & $40 \% \mathrm{BA}$ & 8.47 & 8.64 & 0.02 & 7.20 \\
\hline 7 & $50 \% \mathrm{BA}$ & 8.67 & 9.26 & 0.02 & 7.81 \\
\hline
\end{tabular}

\subsection{Sorptivity Test}

The raise of water in concrete due to capillary movement of water in concrete is called sorptivity. The 28, 56, 90 days cured specimens of $150 \mathrm{~mm}$ x $150 \mathrm{~mm}$ x $150 \mathrm{~mm}$ were used for the test. The specimens were oven dried for a period of 24 hours at a temperature of $105^{\circ} \mathrm{C}$. The dried specimens were cooled and placed for testing in such a manner that only bottom $2 \mathrm{~mm}$ to $5 \mathrm{~mm}$ depth of specimen is immersed in water. The weight of specimen at regular interval is taken until the difference between two alternative readings become constant. The sorptivity is calculated by the formula

\section{Sorptivity $=((\mathbf{Q} / \mathbf{A}) / \sqrt{ } \mathbf{t})$}

Where, $Q=$ Quantity of water absorbed in $\mathrm{mm}^{3}$

$\mathrm{A}=$ Area in contact with water in $\mathrm{mm}^{2}$

$\mathrm{t}=$ time in seconds

This test of sorptivity showed that the sorptivity value increased with increase in bottom ash content in concrete. This increment was found at all ages of concrete which was due to the porous bottom ash have high affinity towards water.

\subsection{Density of Concrete}

The density of dry concrete was calculated for the specimens by taking the oven dry weight of concrete and volume of specimens. The density was found at 28 days.

Dry density $=$ Dry weight $/$ Volume of specimen 
Table - 5: Sorptivity values of M60 HSGFRC

\begin{tabular}{|l|l|l|l|l|}
\hline \multirow{2}{*}{ Sl. No. } & \multirow{2}{*}{ \% replacement of bottom ash } & \multicolumn{3}{|l|}{ Sorptivity $(\mathbf{m m} \backslash \mathbf{m i n})$} \\
\cline { 3 - 5 } & & $\mathbf{2 8}$ days & $\mathbf{5 6}$ days & $\mathbf{9 0}$ days \\
\hline 1 & CC & $0.728 \times 10^{-4}$ & $0.673 \times 10^{-4}$ & $0.638 \times 10^{-4}$ \\
\hline 2 & $0 \%$ BA & $0.883 \times 10^{-4}$ & $1.070 \times 10^{-4}$ & $1.059 \times 10^{-4}$ \\
\hline 3 & $10 \%$ BA & $1.015 \times 10^{-4}$ & $1.225 \times 10^{-4}$ & $1.269 \times 10^{-4}$ \\
\hline 4 & $20 \%$ BA & $1.181 \times 10^{-4}$ & $1.236 \times 10^{-4}$ & $1.324 \times 10^{-4}$ \\
\hline 5 & $30 \%$ BA & $1.236 \times 10^{-4}$ & $1.335 \times 10^{-4}$ & $1.335 \times 10^{-4}$ \\
\hline 6 & $40 \%$ BA & $1.258 \times 10^{-4}$ & $1.468 \times 10^{-4}$ & $1.424 \times 10^{-4}$ \\
\hline 7 & $50 \%$ BA & $1.457 \times 10^{-4}$ & $1.589 \times 10^{-4}$ & $1.589 \times 10^{-4}$ \\
\hline
\end{tabular}

Table - 6: Density of M60 HSGFRC

\begin{tabular}{|l|l|l|}
\hline $\begin{array}{l}\text { Sl. } \\
\text { No. }\end{array}$ & $\begin{array}{l}\text { \% replacement of } \\
\text { bottom ash }\end{array}$ & $\begin{array}{l}\text { Density of concrete } \\
\left(\mathbf{k g} / \mathbf{m}^{\mathbf{3}} \mathbf{)}\right.\end{array}$ \\
\hline 1 & CC & 2479.75 \\
\hline 2 & $0 \%$ BA & 2469.50 \\
\hline 3 & $10 \%$ BA & 2396.00 \\
\hline 4 & $20 \%$ BA & 2378.50 \\
\hline 5 & $30 \%$ BA & 2363.25 \\
\hline 6 & $40 \%$ BA & 2346.66 \\
\hline 7 & $50 \%$ BA & 2324.00 \\
\hline
\end{tabular}

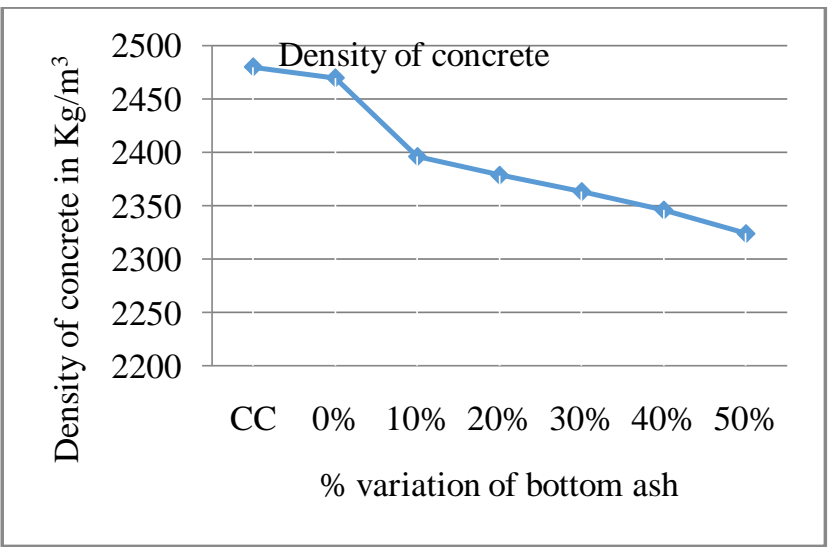

Chart - 1: Density values of M60 HSGFRC at 56 days

\section{CONCLUSIONS}

$>$ Workability of concrete with bottom ash and fibers reduces with increases in bottom ash increment which is due to the more absorption capacity of bottom ash.

$>\quad$ The compressive strength at 28 days decreases with increase in bottom ash content which is due to the lower hydration of fly ash at lower ages.

$>\quad$ The compressive strength increases at 56 and 90 days up to $40 \%$ which is maximum replacement level but overall up to $50 \%$ replacement of bottom ash can be made with constant levels of fly ash and silica fume.

$>$ Acid resistance test showed that the concrete with fly ash, silica fume, bottom ash and glass fibers are more resistant up to a $30 \%$ replacement level of bottom ash.

$>$ The sorptivity test showed an increase in sorptivity with increase in bottom ash percentage increment in concrete which is due to bottom ash has a greater affinity to water.

$>\quad$ The concrete density decreased with increase in bottom ash in concrete which is a good sign that is due to lesser specific gravity of bottom ash.

$>\quad$ The rebound hammer test gave the rebound values which can be correlated with the strength of concrete.

$>$ UPV test showed a decrease in pulse velocity with increase in bottom ash content but the concrete is excellent up to $30 \%$ replacement of sand with bottom ash.

\section{REFERENCES}

[1]. Arun kumar A, A.S. Santhi and G.Mohan Ganesh, "Strength and Drying Shrinkage of Green Concrete" Indian Concrete Journal, Vol. 88, Feb 2014.

[2]. H S Jadhav and R R Chavarekar "Role of Fly Ash and Silica Fume on Compressive Strength Characteristics of High Performance Concrete", IJSCER Vol. 2, No. 1, Feb 2013

[3]. Girish.S, Karisiddappa and Amar.R "Experimental Study to Obtain Optimum Replacement Percentage of Flyash and Addition of Silica Fume in Blended Concrete", International Journal of Research (IJR) Vol.-1, Issue-7, Aug 2014

[4]. Dilip Kumar Singha Roy and Amitava Sil, "Effect of Partial Replacement of Cement by Silica Fume on Hardened Concrete", International Journal of Emerging Technology and Advanced Engineering, Vol. 2, Issue 8, August 2012

[5]. Avinash Gornale, S Ibrahim Quadri, S Mehmood Quadri, Syed Md Akram Ali and Syed Shamsuddin Hussaini., "Strength Aspects of Glass Fiber Reinforced Concrete", International Journal of Scientific \& Engineering Research, Vol. 3, Issue 7, July-2012

[6]. P. Bhuvaneshwari and R. Murali, "Strength Characteristics of Glass Fiber on Bottom Ash Based Concrete", International Journal of Science, Environment and Technology, Vol. 2, No 1, pp. 90102, 2013.

[7]. P. Aggarwal, Y. Aggarwal and S.M. Gupta, "Effect of Bottom Ash as Replacement of Fine Aggregates in Concrete", Asian Journal of Civil Engineering (Building And Housing) Vol. 8, No. 1 (2007).

[8]. Deshmukh S.H., Bursary J. P and Zoned A. M. "Effect of Glass Fibers on Ordinary Portland cement 
Concrete", IOSR Journal of Engineering, June. 2012, Vol. 2(6) pp. 1308-1312.

[9]. Abdulhameed Umar Abubakar and Khairul Salleh Baharudin, "Properties of Concrete Using TANJUNG BIN Power Plant Coal Bottom Ash and Fly Ash", International Journal of Sustainable Construction Engineering \& Technology (ISSN: 2180-3242), Vol. 3, Issue 2, 2012

[10].M.T.Ramteke, V.K.Gajghate and Dr. A.M.Pande, "Analysis of Interrelationship Between Destructive and Non-destructive Compressive strength, Dynamic Modulus of Elasticity and Ultrasonic Pulse Velocity of Concrete Materials", International journal of engineering innovation and research(ISSN: 22775668), Vol. 4, Issue 4, 2015

[11]. Arkamitra Kar, Udaya B. Halabe, Indrajit Ray, Avinash Unnikrishnan, "Nondestructive Charecterizations of Alkali Activated Fly Ash and/or Slag Concrete", European Scientific Journal(ISSN 1857-7881), Vol. 9, August 2013 